Studia Judaica 20 (2017), nr 1 (39), s. 105-124

doi:10.4467/24500100STJ.17.005.7731

Brian Horowitz

\title{
Vladimir Jabotinsky: A Zionist Activist on the Rise, 1905-1906
}

\begin{abstract}
This study of Vladimir Jabotinsky in the years 1905-1907 reveals a developmental leap in his evolution as a politician, thinker, and Zionist leader. In this context one should view his political activities and his writings as two elements of a united system that had the goal of advancing Zionism in Russia. Although this observation might seem self-evident, it has epistemological significance because it warns us against exaggerating Jabotinsky's importance exclusively as a thinker. At that time Jabotinsky was an inexperienced political strategist and politician of middling, but growing, importance. However, he learned quickly and advanced in the leadership during this short period. The author examines how he succeeded satisfying his ambitions through practical affairs and literary polemics.
\end{abstract}

Keywords: Revolution of 1905, Vladimir Jabotinsky, Zionist movement, Jewish politics.

\section{Epistemological Issues}

This study is part of a larger project that aims to peel away the myths that have accumulated about Vladimir Jabotinsky (1880-1940), the Russianborn, Revisionist-Zionist leader. The goal of reexamining documents of the tsarist period, including newspaper articles, letters, and memoirs, in order to get a more accurate understanding of Jabotinsky has some urgency despite the amount of time that has passed. According to Jan Zouplna, a scholar of Zionism, the flaws in scholarship on Revisionist Zionism in general and Jabotinsky in particular are acute:

The common approach of Israeli academia, successfully exported elsewhere, has indeed affected the overall picture of the Revisionist movement at our disposal. 
Particular periods of Revisionist history are dealt with unevenly, the main criteria not being the actual importance of the period but their relevance to the complex and intertwined network of contemporary Israeli politics. As a consequence, the "hot" ideological issues apparently dominate any attempt to grasp history, its effect upon the formulation of Revisionist ideology itself included. . . Ze'ev Jabotinsky, the icon of the Israeli right, still continues to haunt academia, disguised in the ghost-like existence of a revered mentor and preacher of Zionist ideological maximalism, regardless of the amount of material assembled. The fact that the findings of the (mainly, but not exclusively) Israeli historiography often rest on a more or less dubious methodology ... [and] at least partially explains why many of the obsolete notions still exist side by side with more critical assessments. ${ }^{1}$

Certainly, the interference of present-day Israeli politics in Zionist historiography is one cause for the distortion of Jabotinsky's overall image-his portrayal as enemy number one for the political left and sacrosanct hero for the right. However, another cause is the accretion of myths and legends that have given rise to images that diverge from historical facts. ${ }^{2}$ One of the stubborn myths of Jabotinsky's early years is that in his Russian years Jabotinsky was a major thinker. ${ }^{3}$ The proof offered is that he designed the new Zionist program (Synthetic Zionism) in 1905 and shepherded its passage at the Helsingfors Conference in 1906. Are these claims true?

Independent of an evaluation of Jabotinsky's status as a thinker, there is another question that has greater importance for understanding Jabotinsky's evolution - that of the relationship between Jabotinsky's writings and his political activity. A study of Jabotinsky between 1905 and 1907 reveals the way his writings work to buttress his political activity during the revolutionary year and then in the context of the Duma election campaigns. In this way one should not consider his political activities and his writing as separate endeavors, but regard them as two elements of a united system that had the goal of advancing his Zionist politics. Although this observation might seem self-evident, it has epistemological significance

${ }^{1}$ Jan Zouplna, "Revisionist Zonism: Image, Reality and the Quest for Historical Narrative," Middle Eastern Studies 44 (2008), 1: 23.

${ }^{2}$ For a summary of some of the recent images of Jabotinsky in Israeli discourse, see Arye Naor, "Jabotinsky's New Jew: Concept and Models," The Journal of Israeli History 30 (2011), 2: 141-159.

${ }^{3}$ See, for example, Arye Naor's biographical sketch in Vladimir Jabotinsky, Leumiyut liberalit, ed. Arye Naor (Tel Aviv, 2013), 14-20. Christoph Gassenschmidt calls Jabotinsky in 1905 a "chief Russian Zionist ideologist." Recently we found another exponent of this viewpoint in Svetlana Natkovich. See Bin inyanei zoher: yatsirto shel Vladimir (Ze'ev) Jabotinsky veha-kesher ha-hevrati (Jerusalem, 2015). 
because it poses an objection against exaggerating Jabotinsky's importance as a thinker. In my interpretation, Jabotinsky was an inexperienced political strategist and politician of middling, but growing importance who enlisted his pen to win over the public for his activities. To evaluate the relationship between his writing and actions, I propose an examination of one short period, 1905-1907-the year of revolution and the First and Second Dumas-to see what was actually going on. This study should permit us to separate image from reality, as well as to consider whether Jabotinsky appeared as a leader from the start or whether he developed gradually, gaining vital experience in 1905-1907.

\section{Jabotinsky before 1905}

There was a tectonic shift in Zionism's political atmosphere between 1904 and 1905. ${ }^{4}$ In 1904, Zionists in Russia were still intensely occupied with the Uganda Affair and reeling from Theodor Herzl's death. ${ }^{5}$ Although Herzl had won a slim victory at the Zionist Congress in 1903 regarding Jewish colonization of Uganda, many Russian Zionists, including Jabotinsky, opposed Herzl's plan and held stubbornly to Palestine as Zionism's exclusive goal. ${ }^{6}$ At the sixth Zionist Congress, the first after Herzl's death, a majority rejected Uganda and regarded Palestine once again as the sole end-goal of the movement.

In 1904, Jabotinsky decided to leave his home in Odessa for St. Petersburg, where he had been invited to join the editorial board of the new newspaper Evreiskaia Zhizn' [Jewish Life], the first Zionist newspaper published in the Russian language. ${ }^{7} \mathrm{He}$ arrived in time to contribute to the paper's inaugural issue in April. ${ }^{8}$ In his autobiography Jabotinsky described his transplantation to St. Petersburg as caused by the need

${ }^{4}$ Oleg Budnitsky, "Evrei i revoliutsii 1905 goda v Rossii: vstrecha s narodom," Neprikosnovennyi Zapas 6 (2005), 44: 99-104.

${ }^{5}$ Efim Chlenov, Polozhenie sionizma v Rossii: K VII-mu kongressu (St. Petersburg, 1905), 21.

${ }^{6}$ Yossi Goldstein, "Herzl and the Russian Zionists: The Unavoidable Crisis?", Studies in Contemporary Jewry 2 (1986), 216; see also Yosef Klausner, Opozitsyah le-Herzl (Jerusalem, 1960).

${ }^{7}$ Vladimir Jabotinsky, Story of My Life, eds. Brian Horowitz, Leonid Katsis (Detroit, 2016), 73.

${ }^{8}$ At the same time he was also invited to write for Rus', a liberal newspaper edited by the son of the anti-Jewish publisher, Aleksei Suvorin. 
to flee an arrest warrant in Odessa. ${ }^{9}$ Although the police in Odessa had sought his arrest, nonetheless, like many provincials he yearned for fame and a bigger stage in Russia's capital city. ${ }^{10}$

In St. Petersburg Jabotinsky grew close to the intellectuals who contributed to Jewish Life. ${ }^{11}$ They congregated around the newspaper's editor, Avram Idel'son, an experienced journalist and imaginative intellectual who arrived to his position in late 1905, several months after the newspaper had begun appearing. The group of youths were known according to the unusual name, Halastra-Polish for a collective or group. Members of the Halastra included Idel'son, Yuly Brutskus, Daniil Pasmanik, Shlomo Gepstein, Alexander Goldstein, Arye Babkov, Arnold Seiderman, Max Soloveichik, and Moshe Zeitlin. ${ }^{12}$

The first issues of Jewish Life were ideologically vague. The editor-inchief at the start was Moisei Markovich Margolin, the author of a wellregarded book, Osnovnye techeniia v istorii evreiskogo naroda [Basic Trends in the History of the Jewish People]. ${ }^{13}$ In his opening column, Morgolin appeared to avoid controversial issues. He was silent about the Uganda Affair ostensibly in order not to alienate his audience that might include "Ja-sagers," supporters of Herzl's proposal. Margolin articulated abstract principles. He emphasized that Jews had the right to be considered a separate nation and therefore should stop seeking to assimilate as they have for two thousand years. ${ }^{14}$ According to Yehuda Slutzky, an expert on the Russian-Jewish press, the journal played an important role in leading Russian Zionism from its philanthropic origins to the adoption of a distinctly political role. Since Jabotinsky published extensively in Jewish Life, it is worth knowing that

[the newspaper's] primary purpose was to be a messenger of the new Zionist movement that began with Hibbat Tsion and turned into an official movement

9 Jabotinsky, Story of My Life, 72-73.

${ }^{10}$ Living in St. Petersburg was problematic for Jabotinsky because he did not have the legal right as a Jew to stay in the capital. Only so-called "privileged Jews" had the right to live in St. Petersburg and therefore Nikolai Sorin, the founder of Jewish Life, found Jabotinsky a hotel where a bribe to the police left him untouched.

${ }^{11}$ Yehuda Slutzky, Ha-itonut ha-yehudit-rusit ba-me'ah ha-esrim (1900-1918) (Tel Aviv, 1978), 225-226.

12 Jabotinsky, Story of My Life, 74.

${ }_{13}$ Moisei Markovich Margolin, Osnovnye techeniia v istorii evreiskogo naroda: Etiud po filosofii istorii evreev (St. Petersburg, 1900).

${ }^{14}$ S. n. [Moisei Markovich Margolin], "O zadachakh Evreiskoi Zhizni," Evreiskaia Zhizn' 1 (1904), 1. 
"only in 1897 at the First Congress at Basel." There the idea of the Jewish people was realized and formulated clearly and solidly. With these words the newspaper clearly defined its line to be the mouthpiece of political Zionism in contrast to Hibbat Tsion and the followers of "Spiritual Zionism."15

Slutzky gave a general account, but did not deal with the rapid changes in the journal that occurred in late 1905, with the appointment of Avram Idel'son as editor-in-chief. Jabotinsky's first articles in Jewish Life in 1904 reflected the journal before Idel'son's arrival. These dealt with the political crises of the day, the Uganda Affair and Herzl's death. Jabotinsky's "Question of the Day" in the first issue spelled out problems known to everyone:

One has to say loudly and directly that the Zionist movement is experiencing a difficult crisis. In the south, for example, our organization has become noticeably weakened, the fund's shekels and marks are not put to any use, and people start arguments with one another and try to prove that precisely you and not me are guilty for the crisis, and the whole thing has ceased to function because of you. ${ }^{16}$

Acknowledging the Uganda decision, Jabotinsky emphasized his commitment to Palestine. This was hardly a controversial position since the entire Halastra opposed the settlement in Uganda. ${ }^{17}$ At the time of Herzl's death in April 1904, Jabotinsky became something like Russia's official eulogizer. After all, he was a talented wordsmith and popular journalist. Jabotinsky published "Hêsped," a poem of praise, and an article, "Sidia na polu..." ["Sitting on the Floor"], about the pain he and others felt about Herzl's death. ${ }^{18}$

\section{Jabotinsky and the 1905 Revolution}

A great deal changed in Russian Zionism during the year 1905 and these changes found a reflection in Jewish Life. When the revolution unfolded in earnest, Jabotinsky urged Jews to get involved. In "Nabroski bez zaglaviia" [Sketches without a Title], published in Jewish Life in April 1905, Jabotinsky argued:

${ }^{15}$ Slutzky, Ha-itonut ha-yehudit-rusit, 206.

${ }_{16}$ Vladimir Jabotinsky, “Va vopros dnia (fel'eton),” Evreiskaia Zhizn' 1 (1904), 204.

17 Vladimir Jabotinsky, O territorializme (Sionizm i Palestina) (Odessa, 1905), 3.

${ }_{18}$ Vladimir Jabotinsky, "Hêsped," Evreiskaia Zhizn' 13 (1905); id., "Sidia na polu...," Evreiskaia Zhizn’ 14 (1905), 17. 
But when we grow old and grey and the question is posed to us by the next generation, how will we justify ourselves and on what will we rely? Our epoch does not resemble the age of our fathers. A sleepy silence hovered over them, around us there is noise and commotion: something is falling apart, something else is being created, thousands of scouts seek thousands of new paths, new banners flicker in the sky and new words thunder- "the ice is coming," it thunders and breaks everything that tries to oppose it, cracking, bending and breaking into tiny pieces everything that resists. He who is blessed to live through this wave and also into old age and arrives at the Passover night with empty hands-what will he say to his children in response to their justified question, "Ma." 19

For himself at least, Jabotinsky had an answer. He decided to devote himself to political activism and polemical writing. Between 1905 and 1906, he was a representative on behalf of Zionism in the League for the Attainment of Full Rights among the Jews of Russia (Soiuz dlia dostizheniia polnopraviia evreiskogo naroda $\mathrm{v}$ Rossii). He also played a productive role in the organization of Russian Zionism as a member of the leading faction, Zionei Zion. For example, Jabotinsky helped produce two conferences of Zionist delegates, one in November 1905 in St. Petersburg and the other in November 1906 in Helsinki. As a polemicist, he published (in Russian) six pamphlets: Ten Books: A Dialogue, To the Enemies of Zion, The Bund and Zionism, Jewish Education, On Territorialism, and Critics of Zionism, dozens of articles in Jewish Life, and an introduction to a Russian translation of State and Nation by Karl Renner.

In March 1905, the League for the Attainment of Full Rights among the Jews of Russia held its first meeting. ${ }^{20}$ Jewish liberals (primarily members of the Constitutional Democratic [Kadet] Party) conceived

19 Vladimir Jabotinsky, “Nabroski bez zaglaviia,” Khronika Evreiskoi Zhizni 14 (1905), 8.

${ }^{20}$ There is a relatively lengthly secondary literature on the League for the Attainment of Full Rights for the Jews of Russia. The most informative include Christoph Gassenschmidt, Jewish Liberal Politics in Tsarist Russia, 1900-1914: The Modernization of Russian Jewry (New York, 1995); Viktor Kel'ner, "Nesostoiavshiisia soiuz (Soiuz dostizheniia polnopraviia evreiskogo naroda v Rossii v dokumentakh i memuarakh)", unpublished article made available by the author; David Vital, Zionism: The Formative Years (Oxford, 1982), 389; Elie Vovshin, "Tahalikh ha-hitigabesh shel yahadut Rusyah le-or peilut ha-brit lehasagat milo ha-zehhuyot ever ha-am ha-yehudi be-Rusyah bi-tekufat ha-mahapekhah ha-rusit ha-rishona, 1905-1907" (Ph.D. dissertation, University of Haifa, 2008). See also such primary sources as Protokoly tret'ego delegatskogo s'ezda Soiuza dlia dostizheniia polnopraviia evreiskogo naroda $v$ Rossii (Obshchestva polnopraviia evreiskogo naroda $v$ Rossii) v S.-Peterburge s 10-go po 13-oe fevralia 1906 g. (St. Petersburg, 1906), and the memoir by Shimon Dubnov, Kniga zhizni: materialy dlia istorii moego vremeni, vospominaniia i razmyshleniia (Moscow, 2004), 281-287. 
of the organization's purpose as uniting internal Jewish political efforts in order to link them with the liberal movement. ${ }^{21}$ The liberals favored a democratic republic and Rechtsstaat, including equal rights for Jews. ${ }^{22}$ Although representatives of various political orientations were invited, Bundists, Jewish Social Democrats, and members of the newly formed Poale Zion refused, while Zionists agreed to join. Jabotinsky was elected as a representative for the Zionists.

Some ideological principles — such as the desire to attain civic rights as citizens of a democratic Russian state-united Zionists with Jewish liberals. But they diverged from liberals in demanding national rights, such as a national assembly and national educational and cultural institutions, schools, theaters, lectures, etc. Speaking philosophically, Zionist participation in the Russian Revolution of 1905 was not an obvious move and might be seen as a shift in tactics, if not strategy. ${ }^{23}$ If one might identify a general view on the Diaspora among Zionists, it was negative. Over centuries rabbis had spoken of a "negation of the exile" (shlilat hagalut), and Zionists had adopted the idea as a theoretical principle, albeit unattainable in practice. ${ }^{24}$ Jabotinsky was less dogmatic about a blanket dismissal of Jewish life outside Israel. Already in 1903, Avram Idel'son countered that the Jews could not wait until the conditions were right for massive emigration to Palestine, they had to engage in political struggles to advance Jewish national interests in the present. ${ }^{25}$

Idel'son's ideas not only influenced the Zionist approach to the League, but formed an entirely new conception, Gegenwartsarbeit, known also as Synthetic Zionism, which became codified as policy at the Helsingfors Conference of Russian Zionists in November 1906. ${ }^{26}$ Jabotinsky acknowledged Idel'son's primary role in the creation of Synthetic Zionism. He writes, "The formulation of the Helsingfors program was the fruit of collective work: A. D. Idel'son did not contribute to the text any more than

${ }^{21}$ Viktor Kel'ner, “'Ikh tseli mogut byt' vysoki, no oni - ne nashi tseli' (M. M. Vinaver - antisionist)," Judaica Petropolitana 1 (2013), 116-117.

${ }^{22}$ David Zaslavskii, St. Ivanovich, Kadety i evrei (Petrograd, 1916), 8-9. 229-231.

${ }^{23}$ Yitzhak Maor, Sionistskoe dvizhenie v Rossii, trans. Olga Mintz (Jerusalem, 1977),

${ }^{24}$ See Daniel Weiss, "A Nation without Borders?: Modern European Emancipation as Negation of Galut," Shofar 34 (2016), 14: 71-97.

${ }_{25}$ Avram Idel'son's early articles are reprinted in Sobranie sochinenii (Petrograd, 1919).

${ }^{26}$ Brian Horowitz, Russian Idea - Jewish Presence: Essays on Russian-Jewish Intellectual Life (Boston, 2013), 59-60. 
the other participants in the 'Congress of the Zionist Press' in Vilna. But its entire spirit was Idel'son's." 27

As a vocal representative to the League, Jabotinsky embodied the Zionist resistance to many liberal initiatives, which in fact stemmed from the Kadet (Constitutional Democratic) Party. Zionists and liberals constantly clashed. Liberals held a majority in the League because before the opening of the First Duma most voters believed that an alliance with the Kadet Party would produce the breakthrough on equal rights for Jews. Since liberals held a majority of the delegates, Zionists were given a hearing, but rarely did they manage to gain acceptance of their proposals by the entire legislative body.

At the second meeting of the League in November 1905, for example, Jabotinsky proposed establishing a "Jewish assembly." It was an idea of grave importance to the Zionist delegates, and Jabotinsky defended his demand as follows:

We turn our back on the external world which has turned its back on us a long time ago, and we turn ourselves to an internal, national Jewish policy. It is not necessary to write manifestos to Russian society but to our own Jewish people in order to awaken them to a new life and encourage them to take fate into their own hands. The assembly of this Jewish parliament will be a turning point in the history of the Jewish people..$^{28}$

However, the League's members rejected the proposal.

At the third congress of the League held in February 1906, Jabotinsky and other Zionists supported Shimon Dubnov's demand that League delegates vote as a bloc in the Duma. ${ }^{29}$ That proposal was rejected, as was a statement of preference for the election of Jewish representatives. At the same time the majority voted in favor of a proposal that permitted Jewish Duma delegates to support parties of the right when appropriate, showing thereby that party allegiance outweighed Jewish unity. Jabotinsky, in particular, was disheartened by the unwilliness of liberals to make concessions on issues dearest to the "nationalists."

Analyzing his string of defeats in the League and then defeats in the First Duma, Jabotinsky identified the electoral system as the cause. The

${ }^{27}$ Vladimir Jabotinsky, “U kolybeli Gel'singforskoi programmy," Sbornik pamiati A. D. Idel'sona, eds. Iuly D. Brutskus et al. (Berlin, 1925), 89.

${ }^{28}$ Quoted in Gassenschmidt, Jewish Liberal Politics, 28.

${ }^{29}$ See Simon Rabinovitch, Jewish Rights, National Rites: Nationalism and Autonomy in Late Imperial and Revolutionary Russia (Stanford, 2014), 91-95. 
problem was that voting blocs or curia were based on geographic criteria and class status (city dwellers, rural voters, nobility, etc.). A better system would be the creation of voting curia according to ethnicity. In this way, Jewish voters would have guaranteed representation by Jewish delegates. Moreover, these delegates would be independent of the parties and therefore freed from the compromises that inhibited the advancement of a unified Jewish politics. He writes:

We are absolutely progressive, and we strive for a broad national life, not an underground and fake one. If we had an electorial bloc that reflected the [Jewish] nation, something like national representation, there could never be any mention of an agreement with a party of the right flank of course. But we must "trade" with the parties. . . . It is necessary to rid us of the need to trade with the parties. The best thing would be the realization of the principle of proportional representation. ${ }^{30}$

At the fourth and last congress of the League for the Attainment of Full Rights in May 1906, liberals came under attack from the left and right because their strategy of aligning with the Russian parties had failed to show results. Zionists now saw little to gain by compromising and Jabotinsky wondered out loud whether the League was bringing much if any benefit to the Zionists:

There are two ways to promote Jewish interests: unite or scatter into [separate] parties . . . Because of sad disputes within Jewry, there exists a gradation of opinions on the question of the necessary contour of national rights: Mr. [Mark] Ratner recommends emphasizing even more strongly our lamentable disagreements and fragmentation of actions. The latter would deprive our delegates of any authority and turn the fate of the Jews over to strangers. It is better for us not to have a single delegate than delegates who compromise the Jewish people and emphasize the absence of unity in our national demands. ${ }^{31}$

Christoph Gassenschmidt explains that by the time of the fourth congress,

[T]he gap between the two opposing sides had become so wide that any compromises in terms of their different approaches seemed to be impossible, although the First Duma was still in existence and the failure of the liberals' political approach was not yet foreseeable. ${ }^{32}$

\footnotetext{
${ }^{30}$ Protokoly tret'ego delegatskogo s'ezda Soiuza, 58.

${ }^{31}$ Ibid., 92-93.

32 Gassenschmidt, Jewish Liberal Politics, 41.
} 
After the congress the League disbanded with each of the groups pursuing their own goals with their own individual political parties. Incidentally, in the historical literature the Zionists have been blamed for the breakup of the League. ${ }^{33}$ Viktor Kel'ner, however, has recently exonerated the Zionists, noting that the liberals created their own Jewish political parties at the same time. He writes:

The tactics of the Zionists only pushed the League to its dissolution. In fact, in its depths there already existed several groups that had their own conception about the correct path of the struggle for equal rights. Practically, at this same time the "Jewish People's Group," "The Jewish Democratic Group," and the "Folkspartey" were established. ${ }^{34}$

Since each party was going its own way, in November 1906, at the Third Congress of Russian Zionists (known as the Helsingfors Conference), 72 delegates from 56 cities met in Helsinki, the largest city of the politically autonomous region of Finland, to formulate Zionist policy. ${ }^{35}$ The conference gained the reputation of setting a new path for the movement in Russia because delegates adopted the principle of Gegenwartsarbeit as policy. ${ }^{36}$ According to Joseph Schechtman, the conference was a collective effort:

The Helsingfors program was the product of collective thinking and molding by an exceptionally gifted and brilliant group of Russian Zionist intellectuals: Avram Idelson, Dr. Joseph Lurie, Itzhak Grinbaum, Arnold Seideman, Appolinary Hartglass, Alexander Goldstein, Solomon Gepstein, Daniel Pasmanik, and Leo Motzkin. $^{37}$

Gegenwartsarbeit, known also as Synthetic Zionism, appealed to Jabotinsky in large part because it offered opportunities to participate in

33 Ibid., 48.

${ }^{34}$ Kel'ner, "Nesostoiavshiisia soiuz," 14.

${ }^{35}$ In fact, the conference was organized initially as a meeting of journalists, representatives of the Zionist press, but morphed into a conference of Russian Zionist representatives; similar to the "Russian Vorkonferenz" that usually took place in Western Europe the day before the opening of the official Zionist Congress, Helsingfors was called the Third Congress because the members viewed it as linked to earlier conferences, 1898 in Katowice, and 1902 in Minsk.

${ }^{36}$ For a transcript of the conference, see Evreiskii Narod, nos. 6-8, December 1906. A number of documents from the conference can be found in Hebrew translation in Kitsor: kovets le-korot ha-tenuah ha-tsyonit be-Rusyah (Tel Aviv, 1964), 76-103.

37 Joseph B. Schechtman, Rebel and Statesman: The Vladimir Jabotinsky Story, The Early Years (New York, 1956), 114. 
Russian politics. ${ }^{38}$ Despite his calls for Jews to abandon Russian and head to Palestine, Jabotinsky for one was deeply attached to a Russian cultural orientation. His native language was Russian, as were his cultural heroes, Pushkin, Lermontov, and Goncharov. In addition, he had identified early with the Russian revolutionary movement, and perhaps the values of universal liberation had made a permanent home in his soul. Speculation aside, however, the philosophy of Synthetic Zionism smoothed over the obvious contradiction between work in Palestine and participation in Russian politics, so that one could promote both goals without betraying either.

Synthetic Zionism shifted the Zionist vision toward solving the problems here and now, and steered the movement toward building Jewish culture in the Diaspora, where the vast majority of the Jews lived today. During the Revolution of 1905, Zionists participated in the common struggle against the tsarist regime. Therefore, rather than negating the Galut as a wasteland to be abandoned, Jabotinsky argued that the Diaspora had much to give: preparation for Palestine through work and education, including political education.

With his expert knowledge of Russian, and connections with leading figures in Russian politics, Jabotinsky was particularly well placed to promote Zionism in Russia. Additionally, the Helsingfors Conference helped catapult his status. Although Idel'son was supposed to head the conference, he was arrested in St. Petersburg and could not attend. According to Yossi Goldstein, the Israeli historian, despite the fact that Efim Chlenov served as chairman, it was Jabotinsky's proposals that won over the delegates every time. ${ }^{39}$

Besides giving licence to Russian Zionists to help build the future political life of Jewish in Russia itself, Synthetic Zionism had value for the movement by fusing two contradictory dimensions or time conceptions: the Diaspora today with its struggle for political representation and a "national home" in Palestine as the ultimate solution for the Jewish nation in the future. Synthetic Zionism wonderfully solved the conundrum

${ }^{38}$ Although Idel'son is hardly remembered now, two volumes appeared in his honor after his death: Sefer Idelsohn: Divrei ha-arakhah ve-zikhronot, toledot hayav u-ketavav, eds. Leib Jaffe, Iulii Brutskus, Aleksandr Gol'dshtein (Tel Aviv, 1946); and the above-cited Sbornik pamiati A. D. Idel'sona.

${ }^{39}$ Joseph (Yossi) Goldstein, "Jabotinsky and Jewish Autonomy in the Diaspora," Studies in Zionism 7 (1986), 2: 225. 
of Herzl and Ahad-Ha'am, permitting political solutions and infiltration, international diplomacy and day-to-day cultural revitalization. ${ }^{40}$

Jabotinsky considered the Helsingfors Conference one of the most important events of his life. In his autobiography (1936) he writes:

My conscience compels me to make a bold and impudent confession here: in my heart's inner depths, I feel I am the author of the Helsingfors Program. Of course I am aware that the individual who directed our thinking was not me, but Idel'son; and I also know that all the details of the program—all of them bar none-were worked out and took shape in many conversations during the conference, including those with the members of the Warsaw group and the Odessa group with whom we had permanent contact (Israel Trivus, Nahum Sirkin, Shalom Shwartz, and Hayim Grinberg). Nevertheless, if I did not curb my enthusiasm, I would not hold back, and would fill this page with evidence proving that precisely me, and nobody else, had the privilege of formulating the final text. However, it is best that I hold back, since those others-and there are perhaps two or even four of them-also feel the same certainty deep in their hearts, and maybe even carry the same page of evidence and the same right. ${ }^{41}$

\section{Jabotinsky on Nationalism}

Jabotinsky's writings during 1905-1906 accompanied his political activities by offering partisan explanations and convincing the reader of the justice of his views. Most of this work, his articles in Jewish Life and his pamphlets, were openly propagandistic, lending support to his brand of Zionism. As already mentioned, Jabotinsky's ideological message became transformed from 1904 to 1905, from a concern with Uganda and the world movement to a focus on the situation in Russia: the Jewish role in the revolution, civil and national rights, pogroms, and the elections to the Duma. The writings in 1905-1906 justified his participation in the League for the Attainment of Full Rights for the Jews of Russia and the Helsingfors Conference.

${ }^{40}$ See Brian Horowitz, "What is 'Russian' in Russian Zionism: Synthetic Zionism and the Fate of Avram Idel'son," in id., Russian Idea - Jewish Presence, 54-71; Leib Cherikover, "Avram Davidovich Idel'son," in Sbornik pamiati A. D. Idel'sona, 23. Abram Idel'son introduced Jabotinsky to Synthetic Zionism in 1905, and he became Idel'son's protégé, until they had a falling out by the decade's end. Slutzky, Ha-itonut ha-yehudit-rusit, 205-206.

${ }^{41}$ Jabotinsky, Story of My Life, 91. Hayim Grinberg (or Greenberg, 1889-1953), theorist of Labor Zionism, was head of Poale Zion in the United States. Sholem (Ben-Baruch) Shwartz (1887-1965) was a journalist and editor of the Palestine Daily Bulletin. He was born in Russia and moved to Palestine in 1920. He is the author of such works as The Arab Problem, The Poetry of Tchernichovsky, and Herzl in His Diaries. 
In the December 24, 1905 issue of Khronika Evreiskoi Zhizni [Chronicle of Jewish Life] Jabotinsky mused over the purpose of the League and expressed his disappointment that the delegates could not unite. He complained in print (as he had at the meeting) that the League resisted doing the little good it could do by transforming itself into a Jewish parliament. He writes:

It was impossible to offer programs to the League because for this purpose unification in the League would have been required, and in order to design a program one would have to realize of the necessity of creating a surrogate Jewish parliament. Our mood is clearly characterized by two words-powerlessness and hopelessness. $^{42}$

Jabotinsky's articles not only hung closely to the political activity, there is an aspect in which his articles function as attempts to talk out loud and openly discuss his disappointments. For example, Jabotinsky was among many who reacted strongly to the outbreak of anti-Jewish pogroms in October 1905. However, in contrast to those in the Kadet Party who viewed violence against Jews primarily as a government diversion that should stimulate the continued struggle, Jabotinsky maintained that Jews should concentrate on those things they have the power to change:

We live in a foreign country, we find ourselves dependent on a foreign people. If they want, there will be pogroms and we can die as heroes, but we cannot prevent it. If they don't want it, they won't give us elementary civil equality and we cannot force them because we are a tiny minority. But one thing is in our power: we can call upon the Jewish nation to gather as a unified whole from among the surrounding peoples and formulate our national desires and tasks. ${ }^{43}$

In articles dedicated to the campaign for delegates to the First Duma, Jabotinsky questioned a system that was structurally incapable of electing Jews and therefore providing proper representation. The problem, as he diagnosed it, was that a Jew could only win a seat with the help of non-Jews, which rarely occurred. There were exceptions, such as elections in certain urban areas in which Jews composed the majority, but these instances were few and far between. Indeed, Jabotinsky's fears were realized when not a single Jewish representative was elected in Congress Poland. Even the election of the twelve Jewish representatives to the First Duma, often

42 Vladimir Jabotinsky, "S’ezd soiuza polnopraviia," Khronika Evreiskoi Zhizni 48-49 (1905), 36.

${ }^{43}$ Jabotinsky, "Nabroski bez zaglaviia," 15. 
touted as a victory, was not overly impressive when one considers that the First Duma had 488 representatives, and Jews composed four percent of the population.

With the Duma in mind, Jabotinsky thought hard about how to guarantee national rights for minorities in a democracy. This question led him to undertake a study of Austro-Marxism, and especially the work of Karl Renner, because Renner had formulated several answers with real-world consequences for a parliament in which minorities (Czechs, Slovaks, Slovenians, etc.) vied for their share of resources. ${ }^{44}$ Jabotinsky was already familiar with ideas of cultural autonomy for Jews in Russia, which were articulated by Shimon Dubnov who published his essays on Jewish nationalism, O starom i novom evreistve [On Old and New Judaism], between 1897 and 1904. ${ }^{45}$ Dubnov, a well-known historian of Jewry, proposed autonomy, i.e. the establishment of independent Jewish cultural institutions, schools, libraries, theaters, which made use of the people's native language, Yiddish. ${ }^{46}$ At the same time Dubnov demanded equal rights for Jews as individual citizens in line with the program of the Constitutional Democratic Party (Kadets). ${ }^{47}$

Jabotinsky was not satisfied with Dubnov's paradigm. Exploring a more expansive conception of national rights, in 1906 Jabotinsky published a Russian translation of Karl Renner's State and Nation with his own introduction. ${ }^{48}$ Jabotinsky liked that Renner envisioned unique and separate political and legal institutions for each nationality. Furthermore, Renner wanted to confer rights on minorities even in territories where they made up only a small percentage of the population. This conception of national rights went further than Dubnov's. Jabotinsky mocked Dubnov: "To respond to Jewish pogroms or Armenian slaughter with 'cultural' autonomy means simply to joke around." 49

Jabotinsky was impressed with the idea that different conceptions of law and legal procedures should be assigned to nationalities based on a historical precedent. This approach would enable nations to preserve their own

${ }^{44}$ Walter Rauscher, Karl Renner: Ein österreichischer Mythos (Vienna, 1995).

45 These essays were collected in a single volume and published in 1907 as Pis'ma o starom i novom evreistve [Letters on Old and New Judaism] (St. Petersburg, 1907).

${ }^{46}$ Rabinovitch, Jewish Rights, National Rites.

${ }^{47}$ Shimon Dubnov, Volkspartei: Evreiskaia Narodnaia Partiia (St. Petersburg, 1907), 12.

${ }^{48}$ Vladimir Jabotinsky, "Predislovie," in Rudolph Springer, Gosudarstvo $i$ natsiia (Odessa, 1906), 2-7. (Rudolph Springer is Karl Renner's pseudonym.)

49 Ibid., 4. 
way of life and provide a modified form of political self-determination. Considering whether all of a minority's problems would be solved by the State Duma, Jabotinsky adopted the idea that national identity rather than geographic proximity should give members of a single nation a unified political voice. Thus he made his pitch for a national assembly. He writes:

The task of organizing the nationality question in Russia-if it is truly destined to occur-cannot immediately be fulfilled with a Russian Constituent Assembly, whatever its form and predominant mood would be. In such questions the center, although democratic, cannot be competent. They must await a solution "at the local level." Official and legal national assemblies of every nationality conjoined by territory as well as dispersed should be called into being. In its national assembly each of these nationalities will define the full expanse of its national demands and in this way a special council of representatives from each of the national assembles will smooth out the contradictions between them and, juxtaposing individual demands, formulate a stable modus vivendi. Only this way can the principle of the self-definition of nationalities be realized in the full legal understanding of the word that is expressed in all the advanced programs. ${ }^{50}$

Besides giving praise to Renner, Jabotinsky also drew attention to several problems that inhibited Renner's ideas from gaining traction in Russia. Primarily, Jabotinsky recalled that Jews lacked basic rights permitting the consolidation and strengthening of the nation. In Chronicle of Jewish Life he wrote:

Above all, one has to notice that the concept of "national autonomy" is not exactly the same for Austrian Jews and for us at this time. More precisely, it is two sides of the same concept. The idea of national autonomy includes two features: selfgovernment within the nation and a defense of the nation's interests outside itself. Concretely, this means first, the right to a national organization for the administration of national affairs, and second, the right to national representation in an imperial parliament. ${ }^{51}$

Jabotinsky also noticed that Renner focused exclusively on the application of legal rights for minorities in the case where one nation composed a majority, such as in Austria. This did not correspond to the situation in Russia's western borderlands in which many nations lived side-by-side. He writes:

In the adaptation to Russia's conditions, conclusions necessarily expand. National differences in Russia are far deeper, forms of national dispersion more acute....

${ }^{50}$ Ibid., 7.

51 Vladimir Jabotinsky, “Avtonomiia,” Khronika Evreiskoi Zhizni 48-49 (1905), 19. 
Nationalities need to have the means for the preservation of their independence. But even leaving that sensitive question aside, one cannot forget, for example, that nations everywhere have their own understanding of law that is historically shaped not only in the form of common law, but also in written forms. ${ }^{52}$

Nonetheless, Jabotinsky admired Renner's invitation to imagine membership in a collective beyond conventional ideas of space, geographic cohesion, and population concentration. In that context Jabotinsky envisioned local democratic institutions that would feed into national assemblies. The national assemblies would provide a legal framework to preserve national rights and would include separate courts, schools, and cultural institutions. Jabotinsky envisioned the national assembly as the path to national self-determination:

The furthest development of our nation from ghetto to national state will occur not by means of new growth, not by an expansive rebirth, but by means of the strengthening and consolidation of the national organism. It will not be an escape from a whipping, but a forward movement from down to up, step by step, by means of partial victories toward the final and decisive one..$^{53}$

Certainly, there was a difference between the ideas on autonomy that Jabotinsky modified from Karl Renner and those agreed upon at the Helsingfors Conference, but one could also point out a strong correlation. Jabotinsky's dream-a program of national rights that would include political rights for each separate nation, a national parliament, as well as cultural rights-was inscribed in Helsingfors. The only negative aspect was that part of the Helsingfors program consisted of plans that could only be realized with government support. Would the post-revolutionary tsarist government give that support? The answer turned out negative.

Another example of political activism joined to journalism is his book Bund i Sionizm [The Bund and Zionism], published in 1906. This work was written in the context of the election campaign to the First Duma, when Zionists were trying to sway voters and especially sympathizers to the Bund, since those voters were up for grabs when the Bund rejected participation in the elections. Jabotinsky's gambit was to link the Bund and Zionism and show how sympathy for the Bund validated voting for the Zionists. In the context of the campaign to elect representatives to the Duma, Jabotinsky was saying, if you care about Jewish interests, vote for

\footnotetext{
52 Jabotinsky, "Predislovie," 4.
}

53 Jabotinsky, "Avtonomiia," 18. 
Zionists, since they have always stood for national goals without apologies or compromises.

No one could be blind to the fact that Jabotinsky was attacking the Bund, which was by far the largest political party in the Jewish world, with 35,000 members at its zenith and countless numbers of sympathizers. ${ }^{54}$ Formed in 1897, the Bund assigned itself the mission of representing the Jewish workers through the organization of strikes for higher wages, as well as the promotion of radical politics, such as the overthrow of the tsarist regime. The Bund had played a part in the Russian Social Democratic movement until 1903, when it was ejected because its leaders refused to renounce their commitment to national goals. ${ }^{55}$ The Bund officially rejoined the Social Democratic movement in 1906.

In contrast to those who expressed skepticism about the Bund's commitment to national renewal, Jabotinsky lauded the Bund's national program, especially he maintained the fact that Bund leaders viewed Jews as a nation, an idea that Bundists borrowed from the Zionists. ${ }^{56}$ Jabotinsky, nonetheless, cast doubt on the Bund's commitment to national interests, and claimed that the announcement in favor of national autonomy at the Bund's Fourth Conference in 1901 was a promise that its leaders did not intend to keep. ${ }^{57}$

Comparing the Bund's approach with Zubatovshchina, the tsarist government's concession to socialism, Jabotinsky writes:

I won't equate the Bund with agents of autocracy, but the proposal for national autonomy at the Fourth Congress of the Bund was an act of the national Zubatovshchina. And just as Zubatovshchina was subjectively conceived to destroy Social Democracy, and all the while objectively indicates autocracy's retreat under the pressure of Social Democracy, so too the nationalization of the Bund's program was adopted for a struggle with Zionism, while in reality it is a concession to Zionism. ${ }^{58}$

Zubatovshchina was a policy initiated in the early twentieth century by the tsarist government that permitted strikes for wage concessions

${ }^{54}$ The Bund's official name was the Jewish Workers' Party of Russia, Poland, and Lithuania. See, among many works on the Bund, Joshua D. Zimmerman, Poles, Jews, and the Politics of Nationality: The Bund and the Polish Socialist Party in Late Tsarist Russia, 1892-1914 (Madison, 2003); see also Scott Ury, Barricades and Banners: The Revolution of 1905 and the Transformation of Warsaw Jewry (Stanford, 2012).

55 Jonathan Frankel, Prophecy and Politics: Socialism, Nationalism, and the Russian Jews, 1862-1917 (London, 1981), 238-242.

56 Vladimir Jabotinsky, Bund i Sionizm (Odessa, 1906), 8.

${ }^{57}$ Ibid., 25.

${ }^{58}$ Ibid. 
independent of political goals. ${ }^{59}$ According to many critics, it was a travesty because it permitted the government to hijack the workers' movement in order to tame it. Despite attacks on Zionism by Bundists, Jabotinsky claimed that the Bund and the Zionist movement were not antipodes, but rather "two plants with a single root," two independent movements developing according to their own inner logic. ${ }^{60}$ In this way the Bund promoted Zionism's fundamental ideal among its working class constituents, ultimately leading Jews to that party that stood for Jewish nationalism without reservation, Zionism. Jabotinsky writes:

When the future scholar will write the full history of the Zionist movement, perhaps one chapter in his work in particular will draw the reader's attention. It will follow immediately after chapters on palestinophiles and the philosophy of AhadHa'am. In the [chapter's] beginning, the reader will encounter a review of [Leo] Pinsker's thought, and at the end-the first proclamation of Poale-Tsion. In this chapter, one of Zionism's episodes will be recounted and its will bear the title "Bund." 61

As is well known, Jabotinsky was politically active as a candidate to the Duma, running for the Second Duma as a candidate from Ukraine. ${ }^{62}$ However, he was forced to withdraw his candidacy in order to prevent a split vote and the election of a right-wing delegate. Nonetheless, he ran in elections to the Fourth Duma, where once again he resigned his candidacy in order to attain victory for a liberal.

\section{Jabotinsky in the Aftermath of 1905}

The revolutionary period around 1905 was short. By summer 1907, organized Zionism was outlawed in Russia; provincial leaders were arrested, donations to Keren Kayemet were prohibited, and the movement was paralyzed. ${ }^{63}$ Jewish leaders had either scattered or turned to more productive activities outside of politics. Zionists and Jewish non-Zionists in Russia drew away from Duma politics to devote themselves to "small

${ }^{59}$ Laura Engelstein, Moscow, 1905: Working-Class Organization and Political Conflict (Palo Alto, 1982), 51-59.

${ }^{60}$ Jabotinsky, Bund i Sionizm, 48.

${ }^{61}$ Ibid.

${ }^{62}$ Maor, Sionistskoe dvizhenie v Rossii, 299. See also Jabotinsky, Story of My Life, 78-80.

${ }_{63}$ Maor, Sionistskoe dvizhenie v Rossii, 267-279. 
deeds," philanthropic, educational, and social initiatives.$^{64}$ Jabotinsky left for Vienna where he decided to dedicate himself to the study of national and ethnic rights in a variety of political, legal, and social contexts. ${ }^{65} \mathrm{His}$ research became part of the thesis that he wrote to get a diploma from the University of Yaroslavl, and thus the right to live in Russia proper ${ }^{66} \mathrm{In}$ addition, he published two long articles on national rights in the Russian thick journal Vestnik Evropy [Messenger of Europe]. ${ }^{67}$

An examination of the relationship between Jabotinsky's activity and publications during these years shows that activism was married to his writings, the one served to reinforce the other. Jabotinsky threw his energies into statesmanship and representative politics at the countrywide level, his writings during the period reflect an attempt to advance Zionist politics at the same time.

The years 1905-1906 gave Jabotinsky opportunities to excel as a political leader and theorist, and he took advantage. Before this period he had been a novice, a new face in the leadership, a protégé of Menachem Usishkin and Avram Idel'son. Now Jabotinsky basked in the limelight thanks to a number of high-profile endeavors that gave him political experience and visibility. Although he did not fight tsarism on the barricades with revolutionaries, he used the institutions in which he was involved to advance Jewish civic and political rights, especially national rights. As a delegate to the League for the Attainment of Full Rights for the Jews of Russia, he spoke forcefully for national rights. As a leader in Helsingfors, he won over the majority for Gegenwartsarbeit. As a writer and propagandist, he won over many readers and gained a following in Russian Jewish politics. By 1907, he was a recognized figure, leader, and person of consequence in the movement. He managed to propel himself through his tireless activities and extensive publications. Although he had

${ }^{64}$ See Brian Horowitz, "Partial Victory from Defeat: 1905, Jewish Liberals, and the Society for the Promotion of Enlightenment among the Jews of Russia," in Stefani Hoffman, Ezra Mendelsohn (eds.), The Revolution of 1905 and Russia's Jews: A Turning Point? (Philadelphia, 2007), 117-141.

${ }_{65}$ Jabotinsky, Story of My Life, 94.

${ }^{66}$ Despite the myriad of discriminatory decrees and laws against Jews, one privilege from the time of Alexander II remained valid: Jews with degrees from Russian institutions of higher education had a number of privileges, including the right to live anywhere in the Russian Empire. See Vitalii Nakhmanovich, "Proryv za Chertu (istoriia priniatiia zakona o prave povsemestnogo zhitel'stva kuptsov 1-I gil'dii)," Vestnik Evreiskogo Universiteta v Moskve 2 (1994), 6: 16-40.

${ }^{67}$ Vladimir Jabotinsky, “Samoupravlenie natsional'nogo men'shinstva," Vestnik Evropy 117 (1913), 38: 131-158. 
not started as a leader, his rise was rapid from 1905 to 1907. But even this quick catapult was not conclusive. Jabotinsky post- 1907 was still a secondary figure who hovered near the top rung figures in Russian Zionism. But he had boundless energy that pushed him to new initiatives-the formation of a university in Eretz Yisrael, the propagation of Hebrew in the Diaspora, and the construction of Zionist schools. However, it is true that at the end of that short epoch, he had a much higher status in the movement, a status that permitted him in time to challenge those in the leadership who had earlier provided him with aid and support.

Regarding the use of Jabotinsky's reputation and the distortions of his image through history, it is hard to see how his activities as a writer and political figure in 1905-1907 could be used by anyone. Presumably, most of these debates focus on issues in Israel and are not relevant here, except as a corrective to avoid error. However, the period under inspection does tell us several important things; by 1905 Jabotinsky had broken with socialism, Marxism, and the inexorable triumph of the working class. He had embraced compromise. He was ready to join forces with non-Zionists to gain political leverage in Russia, ready to run and win elections in diverse coalitions. He could talk like a hard-liner, but back down later; he could rouse his supporters, but disappoint them to attain other goals. However, all in all, he was true to Zionism and to the Zionist political party which he, along with several others, had created and now directed.

Brian Horowitz

Tulane University horowitz2@gmail.com 